\title{
Attributes of the soil with cactus pear under organic fertilization, different spacings and sampling times
}

\author{
Milton C. Padilha Junior' ${ }^{1}$ Sérgio L. R. Donato ${ }^{2}$, Paulo E. R. Donato² \& João A. da Silva ${ }^{2}$ \\ ${ }^{1}$ Instituto Federal de Educação, Ciência e Tecnologia Baiano/Setor de Agricultura/Mestrado Profissional em Produção Vegetal no Semiárido, Guanambi, \\ BA, Brasil. E-mail: padilhajrmc@gmail.com (Corresponding author) - ORCID: 0000-0003-0823-7865 \\ ${ }^{2}$ Instituto Federal de Educação, Ciência e Tecnologia Baiano/Setor de Agricultura, Guanambi, BA, Brasil. E-mail: sergio.donato@ifbaiano.edu.br - ORCID: \\ 0000-0002-7719-4662; joao.silva@ifbaiano.edu.br - ORCID: 0000-0001-5358-356X; paulo.donato@ifbaiano.edu.br - ORCID: 0000-0001-8696-8378
}

\begin{abstract}
The objective of this study was to evaluate the chemical attributes of the soil cultivated with 'Gigante' cactus pear under different doses of organic fertilizer, planting spacings and sampling times. Four doses of organic fertilizer with bovine manure $\left(0,30,60\right.$ and $90 \mathrm{Mg} \mathrm{ha}^{-1}$ year $\left.^{-1}\right)$, three spacings $(1.0 \mathrm{x} 0.5,2.0 \mathrm{x}$ 0.25 and $3.0 \times 1.0 \times 0.25 \mathrm{~m})$ and three sampling times $(0,390$ and 600 days after planting) corresponding to the periods prior to planting, growth and harvest of the first cycle, were evaluated in a randomized block design in a $4 \times 3 \times 3$ factorial scheme, with three repetitions. The $\mathrm{pH}$ in water, macronutrients $(\mathrm{P}, \mathrm{K}, \mathrm{Ca}, \mathrm{Mg})$, micronutrients $(\mathrm{B}, \mathrm{Cu}, \mathrm{Fe}, \mathrm{Mn}, \mathrm{Zn})$, variables of the soil sorption complex $(\mathrm{H}+\mathrm{Al}, \mathrm{SB}, \mathrm{CEC}, \mathrm{T}, \mathrm{V})$ and soil organic matter (SOM) were determined. Organic fertilization increased the values of SOM, P, K, Ca, Mg, SB, $\mathrm{CEC}, \mathrm{T}$ and $\mathrm{V}$ and reduced $\mathrm{H}+\mathrm{Al}$ in soils cultivated with 'Gigante' cactus pear at different times. The doses of manure increased $\mathrm{pH}$ and $\mathrm{Mn}$, regardless of sampling time and spacing. The spacings did not influence the chemical attributes of the soil.
\end{abstract}

Key words: Opuntia, planting arrangements, fertility, nutrients

\section{Atributos do solo com palma forrageira sob adubação orgânica, diferentes espaçamentos e épocas de amostragem}

\begin{abstract}
RESUMO: Objetivou-se com este estudo avaliar os atributos químicos do solo cultivado com palma forrageira 'Gigante' sob diferentes doses de adubo orgânico, espaçamentos de plantio e épocas de amostragem. Foram avaliadas quatro doses de esterco bovino $\left(0 ; 30 ; 60\right.$ e $90 \mathrm{Mg} \mathrm{ha}^{-1}$ ano $\left.^{-1}\right)$, três espaçamentos $(1,0 \times 0,5 ; 2,0 \times 0,25$ e $3,0 \times 1,0 \times 0,25 \mathrm{~m})$ e três épocas de amostragem de solo (0;390 e 600 dias após plantio) correspondentes às épocas antes do plantio, crescimento e colheita do primeiro ciclo, dispostos no delineamento experimental em blocos casualizados em esquema fatorial $4 \times 3 \times 3$, com três repetições. Foram determinados o pH em água, macronutrientes ( $\mathrm{P}, \mathrm{K}, \mathrm{Ca}, \mathrm{Mg})$, micronutrientes $(\mathrm{B}, \mathrm{Cu}, \mathrm{Fe}, \mathrm{Mn}, \mathrm{Zn}$ ), variáveis do complexo sortivo do solo (H + Al, SB, CTC, T, V) e matéria orgânica do solo (MOS). A adubação orgânica incrementou os valores de MOS, $\mathrm{P}, \mathrm{K}, \mathrm{Ca}, \mathrm{Mg}, \mathrm{SB}, \mathrm{CTC}, \mathrm{T}, \mathrm{V}$, e diminuiu o de $\mathrm{H}+\mathrm{Al}$ nos solos cultivados com palma forrageira 'Gigante' em diferentes épocas. As doses de esterco incrementaram o pH e Mn, independentemente de época e espaçamento. Os espaçamentos não influenciaram nos atributos químicos do solo.
\end{abstract}

Palavras-chave: Opuntia, arranjos de plantio, fertilidade, nutrientes 


\section{INTRODUCTION}

Cactus pear (Opuntia sp.) is a plant widely spread in the Brazilian semiarid region but, depending on the intensity of the cut at harvest (Lima et al., 2016), the entire aerial part of the plant is served as fodder, which means that most nutrients extracted from the soil during the crop cycle are exported from the cultivated area (Donato et al., 2017a), which may lead to soil impoverishment.

Changes in the planting spacing of cactus pear (Cavalcante et al., 2014), in population density (Silva et al., 2014), in doses of organic fertilization (Donato et al., 2014a, b), organomineral fertilization (Padilha Junior et al., 2016) or chemical fertilization (Silva et al., 2016b) may interfere with vegetative growth (Donato et al., 2014a; Silva et al., 2016b), nutrient extraction (Silva et al., 2016a; Donato et al., 2017a), nutritional status of the plant (Blanco-Macías et al., 2010; Silva et al., 2012; Donato et al., 2016), nutritional value of forage (Silva et al., 2013; Donato et al., 2014b), light interception, growth and dry matter yield.

Increments in the doses of bovine manure applied to the soil promote greater extraction of nutrients by cactus pear (Donato et al., 2017a), improves the performance of structural characteristics (Donato et al., 2014b), increases the concentrations of phosphorus, nitrogen, potassium and sulfur in the cladodes (Donato et al., 2016) and improves the nutritional value and dry matter yield (Donato et al., 2014a).

There is a lack of specific information on changes in soil chemical attributes in the cactus pear agro-system cultivated with organic fertilization under semiarid conditions, in order to establish a criterion of nutrient balance in the soil that ensures the sustainability of the system. The objective of this study was to evaluate the chemical attributes of a soil cultivated with 'Gigante' cactus pear under different doses of organic fertilization, planting spacings and sampling times.

\section{Material ANd Methods}

The present study was conducted at Instituto Federal Baiano, Campus of Guanambi, Bahia, Brazil, from 2009 to 2011. The municipality of Guanambi, belonging to the Guanambi microregion, is located in the semiarid region, with $14^{\circ} 13^{\prime} 30^{\prime \prime}$ South latitude, $42^{\circ} 46^{\prime} 53^{\prime \prime}$ West longitude and altitude of $525 \mathrm{~m}$. Cactus pear was planted on September 15,2009 , before the rainy season, which began in October, with the first rain occurring on October 8. The cactus pear plantation was established in Oxisol. Rainfall along the experimental period was $1,393.29 \mathrm{~mm}, 611.24 \mathrm{~mm}$ in the first and $782.05 \mathrm{~mm}$ in the second rainy season (Donato et al., 2017a).

Treatments obtained by combining four doses of organic fertilization with bovine manure $\left(0 ; 30 ; 60\right.$ and $90 \mathrm{Mg} \mathrm{ha}^{-1}$ year $\left.^{-1}\right)$, three spacings $(1.0 \times 0.5 ; 2.0 \times 0.25$ and $3.0 \times 1.0 \times 0.25 \mathrm{~m})$ and three soil sampling times $(0 ; 390$ and 600 days after planting, DAP) were arranged in a randomized block design in a $4 \times 3 \times 3$ factorial scheme, with three repetitions. The total area of the plot was $64 \mathrm{~m}^{2}(16 \times 4 \mathrm{~m})$, with a usable area of $16 \mathrm{~m}^{2}(8 \times 2 \mathrm{~m})$, where the soil samples were collected, totaling an area of 2,304 $\mathrm{m}^{2}$.
At the planting spacings used, a population density of 20,000 plants $\mathrm{ha}^{-1}$ was maintained. The land previously occupied with forage sorghum was mowed with a mower attached to the three points of the tractor.

Prior to planting, the soil was sampled to perform chemical and physical analyses, and subjected to the operations of subsoiling, plowing and harrowing. Then, the area was furrowed at the planting spacings equivalent to the treatments preceding the rainy season.

Liming was performed with application of $1 \mathrm{Mg} \mathrm{ha}^{-1}$ of dolomitic limestone in total area based on soil analysis (V\%), in order to supply $\mathrm{Ca}$ and $\mathrm{Mg}$, considering that organic fertilization has low capacity to supply these nutrients.

Organic fertilization was performed in the planting furrow, according to the doses established in the respective treatments. One year after planting, the cactus pear crop was again fertilized beside the plants, at $20 \mathrm{~cm}$ distance, with aged bovine manure from the same corral, following the same doses of 0, 30, 60 and $90 \mathrm{Mg} \mathrm{ha}^{-1}$ year $^{-1}$.

The manure used (Donato et al. , 2016) had the following composition: $\mathrm{OM}=63.73 \mathrm{dag} \mathrm{kg}^{-1}$, ash $=36.27 \mathrm{dag} \mathrm{kg}^{-1}$, total carbon $=29.98 \mathrm{dag} \mathrm{kg}^{-1}$ and $\mathrm{pH}=7.42$, moisture on dry basis (d.b.) at $65{ }^{\circ} \mathrm{C}=16.72 \%$; macronutrient contents: $\mathrm{Ca}$, $\mathrm{Mg}, \mathrm{K}, \mathrm{N}$ and $\mathrm{S}=1.7,0.2,2.5,5.2$ and $2.3 \mathrm{~g} \mathrm{~kg}^{-1}$ (EPA 3051/ APHA 3120B), in this order, $\mathrm{P}=4.7 \mathrm{~g} \mathrm{~kg}^{-1}$ (APHA 4500-CP); micronutrient contents (EPA 3051/APHA 3120B): B, Cu, $\mathrm{Zn}, \mathrm{Mn}$ and $\mathrm{Fe}=2.1,45.2,200.5,391.8$ and 1,932.4 $\mathrm{mg} \mathrm{kg}^{-1}$, respectively; and density $=0.38 \mathrm{~g} \mathrm{~cm}^{-3}$.

The cladodes used for planting were selected in a 'Gigante' cactus pear field with two years without harvest, collected from the middle portion of the plant. After harvest, the cladodes remained in the shade for 15 days for healing and were subsequently planted with widest side in the East/West direction, buried about $50 \%$ in the soil for better fixation.

Five simple soil samples were collected between the rows in each experimental plot and homogenized to form the 36 composite samples at each sampling time, totaling 108 soil samples. These samples were placed in new plastic bags properly identified in relation to the position they occupied within the experimental area.

Subsequently, they were sent to the Soil Analysis Laboratory of Universidade Estadual do Sudoeste da Bahia, Campus of Vitória da Conquista, to determine the following soil chemical characteristics: $\mathrm{pH}$, exchangeable phosphorus $(\mathrm{P})$ potassium $(\mathrm{K})$ and sodium $(\mathrm{Na})$ - Mehlich 1 extractor, calcium $(\mathrm{Ca})$, magnesium $(\mathrm{Mg})$ and aluminum $(\mathrm{Al})-1 \mathrm{M} \mathrm{KCl}$ extractor, hydrogen + aluminum $(\mathrm{H}+\mathrm{Al})$ - pH SMP; sum of bases (SB), cation exchange capacity (CEC), base saturation (V), manganese $(\mathrm{Mn})$ and soil organic matter content (SOM) at 0-20 cm depth.

The data of the evaluated characteristics were subjected to analysis of variance, followed by comparisons between the means of the different spacings and sampling times by Tukey test at $\mathrm{p} \leq 0.05$ and regression analyses for the doses of bovine manure applied to the soil. The criteria used to choose the regression models considered the adequacy of the model to the studied phenomenon, the value of the adjusted coefficient of determination and the significance of the regression coefficients by the t-test. 


\section{Results AND Discussion}

The values of SOM, P, K, Ca, Mg, H + Al, SB, CEC, T and V of the soils cultivated with 'Gigante' cactus pear under organic fertilization at different spacings varied with the interaction ( $p \leq 0.05$ ) between fertilization and sampling time (Figure
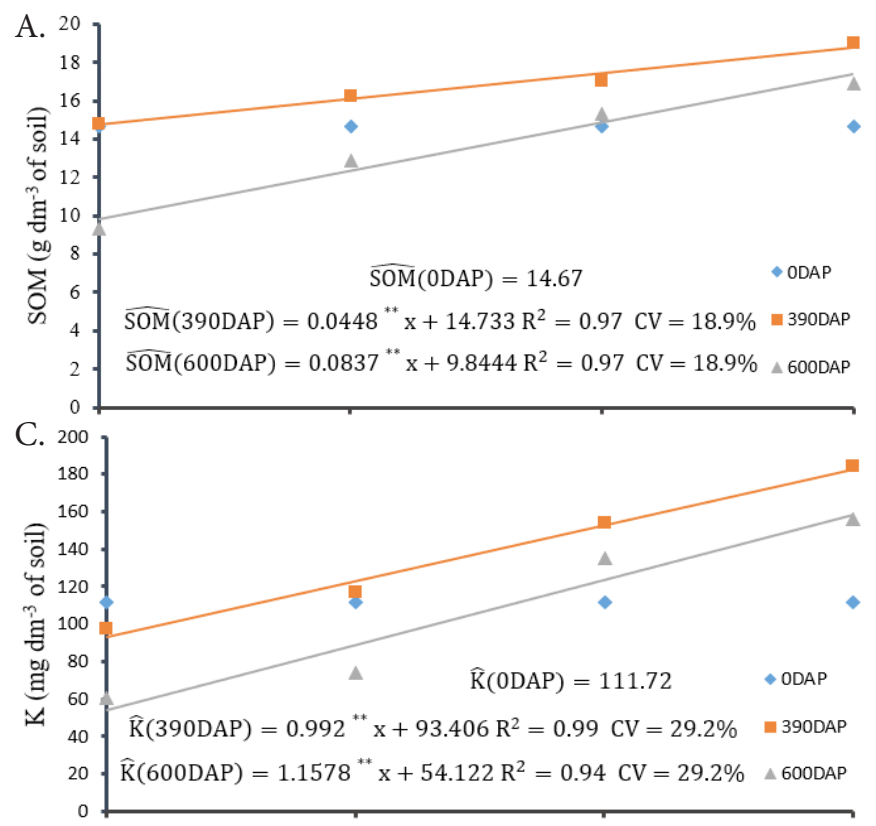

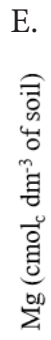
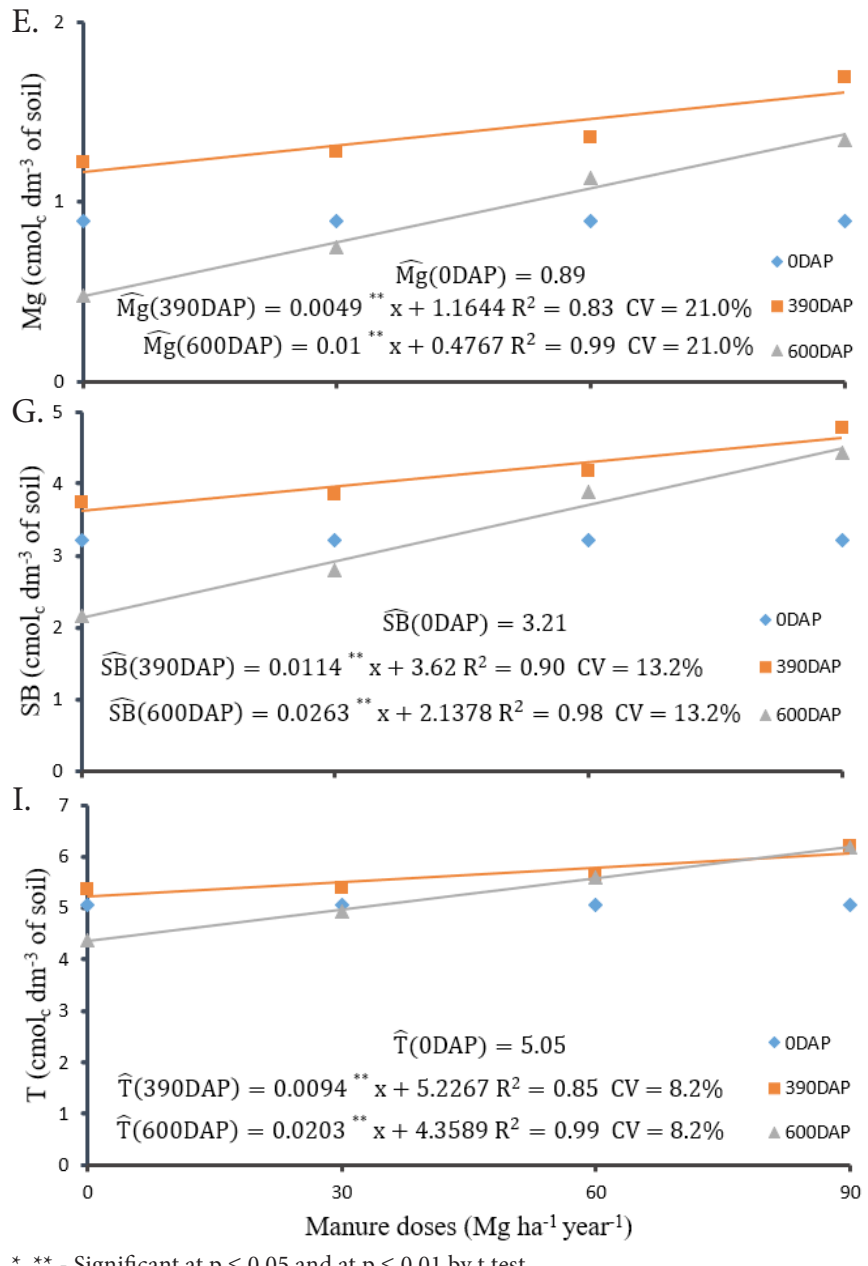

1), while for $\mathrm{pH}, \mathrm{P}, \mathrm{Ca}$ and $\mathrm{V}$ there was interaction ( $\mathrm{p} \leq 0.05)$ between spacing and time (Table 1). The $\mathrm{pH}$ and $\mathrm{Mn}$ contents in the soil varied $(\mathrm{p} \leq 0.05)$ with the fertilizations, regardless of spacing and soil sampling time (Figure 2).

For SOM, P, K, Ca, Mg, H $+\mathrm{Al}, \mathrm{SB}, \mathrm{CEC}, \mathrm{T}$ and $\mathrm{V}$, there were no differences between the manure doses $(\mathrm{p}>0.05)$ at 0
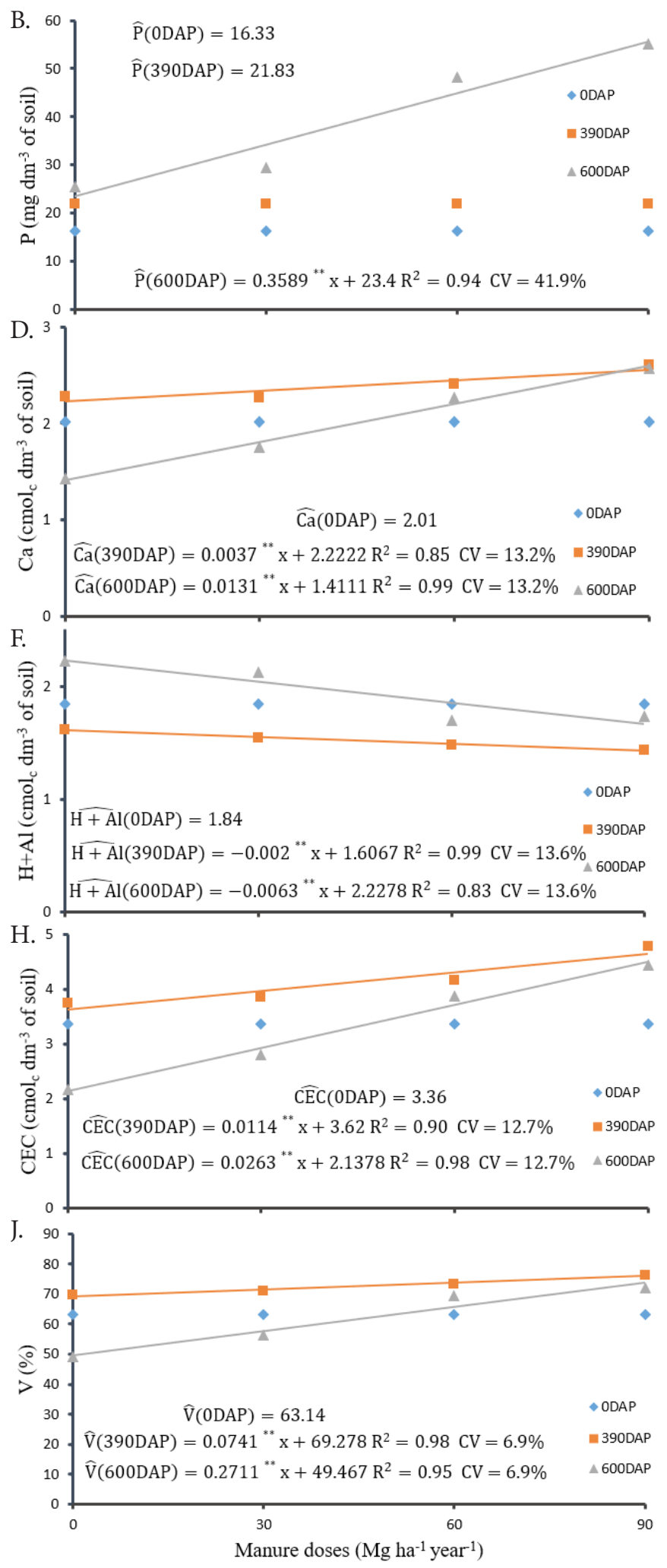

Figure 1. Values of soil organic matter (A), phosphorus (B), potassium (C), calcium (D), magnesium (E), H + Al (F), SB (G), CEC (H), T (I) and V (J) of soil cultivated with 'Gigante' cactus pear as a function of doses of bovine manure at 0,390 and 600 days after planting (DAP) 
Table 1. Chemical attributes of soil cultivated with 'Gigante' cactus pear at different spacings and sampling times

\begin{tabular}{|c|c|c|c|c|c|c|}
\hline \multirow{2}{*}{ Variable } & \multirow{2}{*}{ (un) } & \multirow{2}{*}{$\begin{array}{l}\text { Time } \\
\text { (DAP) }\end{array}$} & $1.0 \times 0.5$ & $2.0 \times 0.25$ & $3.0 \times 1.0 \times 0.25$ & \multirow{2}{*}{$\begin{array}{l}\text { CV } \\
(\%)\end{array}$} \\
\hline & & & & (m) & & \\
\hline \multirow{3}{*}{$\mathrm{pH}$} & \multirow{3}{*}{ (un) } & 0 & 5.56 & $5.47 \mathrm{aB}$ & 5.24 & \multirow{3}{*}{3.99} \\
\hline & & 390 & 6.08 & 5.93 & 6.11 & \\
\hline & & 600 & 5.65 & 5.62 & 5.77 & \\
\hline \multirow{3}{*}{ P } & \multirow{3}{*}{$\left(\mathrm{mg} \mathrm{dm} \mathrm{dm}^{-3}\right)$} & 0 & 23.92 & 15.17 & 9.92 & \multirow{3}{*}{41.89} \\
\hline & & 390 & 21.00 & 19.75 & 24.75 & \\
\hline & & 600 & 35.97 & 41.05 & 41.63 & \\
\hline \multirow{3}{*}{$\mathrm{Ca}$} & \multirow{3}{*}{$\left(\mathrm{cmol}_{\mathrm{c}} \mathrm{dm}^{-3}\right)$} & 0 & 2.23 & 1.98 & 1.83 & \multirow{3}{*}{13.16} \\
\hline & & 390 & 2.45 & 2.31 & 2.41 & \\
\hline & & 600 & 1.96 & 1.92 & 2.12 & \\
\hline \multirow{3}{*}{ V } & \multirow{3}{*}{$(\%)$} & 0 & 65.92 & 62.92 & 60.58 & \multirow{3}{*}{6.88} \\
\hline & & 390 & 73.00 & 71.92 & 72.92 & \\
\hline & & 600 & 59.50 & 61.58 & 63.92 & \\
\hline
\end{tabular}

Means followed by the same uppercase letter in the column or lowercase letter in the row do not differ at $\mathrm{p} \leq 0.05$ by Tukey test ; DAP - Days after planting

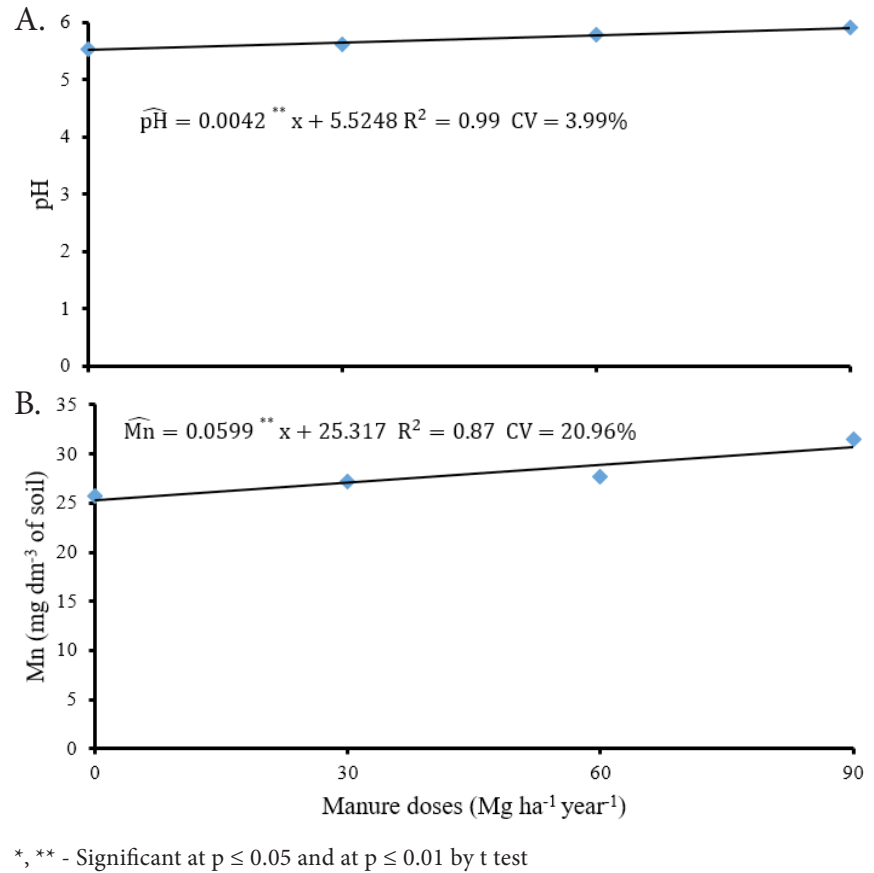

Figure 2. Values of $\mathrm{pH}(\mathrm{A})$ and manganese (B) of soil cultivated with 'Gigante' cactus pear as a function of doses of organic fertilization with bovine manure

DAP, and the following mean values were found: $\mathrm{SOM}=16.67$ $\mathrm{g} \mathrm{dm}^{-3}, \mathrm{P}=16.33 \mathrm{mg} \mathrm{dm}^{-3}, \mathrm{~K}^{+}=111.72 \mathrm{mg} \mathrm{dm}^{-3}, \mathrm{~V}=63.14 \%$, $\mathrm{Ca}, \mathrm{Mg}, \mathrm{H}+\mathrm{Al}, \mathrm{SB}, \mathrm{CEC}$ and $\mathrm{T}=2.01,0.89,1.84,3.21,3.36$ and $5.05 \mathrm{cmol} \mathrm{dm}_{c}^{-3}$, respectively (Figure 1). This result is justified by the homogeneity of the experimental area, as well as by the fact that the first soil sampling was performed before fertilization, which ensured the uniformity of the values in all experimental units at $0 \mathrm{DAP}$.

The values of SOM, K, Ca, Mg, SB, CEC, T and V were described by an increasing linear regression model $(\mathrm{p} \leq 0.05)$ as a function of manure doses at 390 DAP and 600 DAP, while the value of $\mathrm{H}+\mathrm{Al}$ was described by the decreasing linear regression model $(\mathrm{p} \leq 0.05)$ as a function of manure doses at 390 DAP and 600 DAP.

For the second sampling time (390 DAP), the fitted model estimates that the SOM value increases by $0.0448 \mathrm{~g}$ $\mathrm{dm}^{-3}$ for each $\mathrm{Mg} \mathrm{ha} \mathrm{H}^{-1}$ year ${ }^{-1}$ of bovine manure, while for the third sampling time (600 DAP) it estimates an increment of $0.0837 \mathrm{~g} \mathrm{dm}^{-3}$ for each $\mathrm{Mg} \mathrm{ha}^{-1}$ year ${ }^{-1}$ of bovine manure (Figure 1A).
Between the first and second sampling times there was an increase in SOM content as a result of fertilization with bovine manure. At the third sampling time there was a reduction in SOM values due to the mineralization of the fertilizer, but the bovine manure doses of 60 and $90 \mathrm{Mg} \mathrm{ha}^{-1}$ year ${ }^{-1}$ guaranteed the sufficiency levels of SOM (13.0-20.0 $\mathrm{g} \mathrm{dm}^{-3}$ of soil) for 'Gigante' cactus pear (Donato et al., 2017b).

With the increment in bovine manure doses to the soil there is also an increase in the diversity of decomposing microorganisms, which consequently promote mineralization. This becomes more important when considering that bovine manure has a low $\mathrm{C} / \mathrm{N}$ ratio, which tends to contribute to mineralization to the detriment of immobilization.

For $\mathrm{P}$ concentrations, there was a significant effect only at 600 DAP ( $p \leq 0.05)$ as a function of manure doses at 600 DAP. According to the regression equation, the amount of $\mathrm{P}$ increases by $0.359 \mathrm{mg} \mathrm{dm}^{-3}$ for each $\mathrm{Mg} \mathrm{ha}^{-1}$ year $^{-1}$ of bovine manure supplied to the soil (Figure 1B).

It was observed that, even with the increase in the mean P concentration from 16.33 to $21.83 \mathrm{mg} \mathrm{dm}^{-3}$ at the second sampling time, the added value was not enough to reach the $\mathrm{P}$ sufficiency range (22.0-48.0 $\mathrm{mg} \mathrm{dm}^{-3}$ of soil) for the crop (Donato et al., 2017b), under the same soil conditions.

In the semiarid region, due to the low levels of rainfall, the decomposition of manure (bovine, goat, sheep and asinine) is slower in the soil surface. In six months, the decomposition of the manure incorporated to a depth of $10 \mathrm{~cm}$ is equal to $45 \%$ and in the soil surface it is only $15 \%$ (Souto et al., 2005). This fact justifies the significant increase in P concentrations between the first and second sampling times. At 600 DAP, there was a substantial increase of $\mathrm{P}$ as a function of the manure dose applied, which can be explained by the accumulation of two fertilizations with the established doses.

Bovine manure doses of 30, 60 and $90 \mathrm{Mg} \mathrm{ha}^{-1}$ respectively supply to the soil 130-272-75, 260-544-150 and 390-816-225 $\mathrm{kg} \mathrm{ha}^{-1}$ year $^{-1}$ of $\mathrm{N}-\mathrm{P}_{2} \mathrm{O}_{5}-\mathrm{K}_{2} \mathrm{O}$.

The addition of manure to the soil reduces the $\mathrm{P}$ adsorption capacity, increases the concentrations of available $\mathrm{P}$ and $\mathrm{N}$, and promotes greater mobility in the soil profile of soluble organic forms of P and N (Novais et al., 2007), which corroborates the results found in the present study, in which there was a sharp increase the $\mathrm{P}$ concentration in soils grown with 'Gigante' cactus pear.

For the concentration of $\mathrm{K}^{+}$at the second sampling time (390 DAP), the fitted model estimates an increase of $0.99 \mathrm{mg} \mathrm{dm}^{-3}$ 
for each $\mathrm{Mg} \mathrm{ha}^{-1}$ year $^{-1}$ of bovine manure, while for the third sampling time (600 DAP) it estimates an increase of $1.15 \mathrm{mg} \mathrm{dm}^{-3}$ for each $\mathrm{Mg} \mathrm{ha}^{-1}$ year $^{-1}$ of bovine manure (Figure 1C).

At the second sampling time (390 DAP), the fitted model showed an increase in soil $\mathrm{K}^{+}$concentrations for bovine manure doses of 30, 60 and $90 \mathrm{Mg} \mathrm{ha}^{-1}$ year $^{-1}$, followed by a reduction in the concentrations in general at the third sampling time (600 DAP). This can be explained by the fact that $\mathrm{K}^{+}$is the element extracted in largest amount by the cactus pear, clearly demonstrating that the bovine manure dose of $30 \mathrm{Mg} \mathrm{ha}^{-1}$ year-1 $^{-1}$ is not able to guarantee the concentration of the element in the soil within the sufficiency range at the end of the third sampling time (600 DAP), besides demonstrating that the bovine manure dose of $90 \mathrm{Mg} \mathrm{ha}^{-1}$ year ${ }^{-1}$ guarantees the $\mathrm{K}^{+}$concentrations in the soil within the range considered average (sufficient: $100-180 \mathrm{mg}$ $\mathrm{dm}^{-3}$ ) at harvest (Donato et al., 2017b). This can be justified by the low supply of $\mathrm{K}$ by the bovine manure; $\mathrm{r}$ every $30 \mathrm{t}$ of bovine manure added to the soil provide about $75 \mathrm{~kg}$ of $\mathrm{K}_{2} \mathrm{O}$, values that are much lower than the quantities of $\mathrm{N}$ and $\mathrm{P}$ added.

The model fitted for $\mathrm{Ca}^{2+}$ at the second sampling time (390 DAP) estimates that the $\mathrm{Ca}^{2+}$ concentration increases by $0.0037 \mathrm{cmol} \mathrm{dm}^{-3}$ for each $\mathrm{Mg} \mathrm{ha}^{-1}$ year $^{-1}$ of bovine manure, while the model fitted for the third sampling time (600 DAP) estimates an increase of $0.0131 \mathrm{cmol}_{\mathrm{c}} \mathrm{dm}^{-3}$ for each $\mathrm{Mg} \mathrm{ha}^{-1}$ year $^{-1}$ of bovine manure (Figure 1D).

The increment in $\mathrm{Ca}^{2+}$ concentrations in the soil between the first and second sampling times, even in the treatment without organic fertilization, can be explained by the liming operation performed after the first soil sampling, which ensured a uniform increase and, with the addition of manure, in the other treatments, there was a more accentuated increase of $\mathrm{Ca}^{2+}$ for the bovine manure doses of 60 and $90 \mathrm{Mg} \mathrm{ha}^{-1}$ year $^{-1}$.

At 600 DAP, there was a substantial reduction in soil Ca concentration because this is the second element extracted in largest quantity by the cactus pear, only behind $\mathrm{K}$ (Donato et al., 2017a).

For the $\mathrm{Mg}^{2+}$ concentrations at the second sampling time (390 DAP), the fitted model estimates an increase of 0.0049 $\mathrm{cmol}_{c} \mathrm{dm}^{-3}$ for each $\mathrm{Mg} \mathrm{ha}^{-1}$ year ${ }^{-1}$ of bovine manure, while for the third sampling time (600 DAP) it estimates an increase of $0.01 \mathrm{cmol}_{\mathrm{c}} \mathrm{dm}^{-3}$ for each $\mathrm{Mg} \mathrm{ha}^{-1}$ year $^{-1}$ of bovine manure (Figure 1E).

As with $\mathrm{Ca}^{2+}, \mathrm{Mg}^{2+}$ concentrations were high between the first and second sampling times due to the liming operation, with subsequent reduction of the concentrations resulting from the extraction by cactus pear. However, only with the bovine manure doses of 60 and $90 \mathrm{Mg} \mathrm{ha}^{-1}$ year $^{-1}$ the concentrations of $\mathrm{Mg}^{2+}$ remained within the sufficiency range of $1.0-1.6 \mathrm{cmol}_{\mathrm{c}} \mathrm{dm}^{-3}$ (Donato et al., 2017b) at the time of harvest.

According to Donato et al. (2017a), among the macronutrients (N, P, K, Ca, Mg and S) extracted/exported by the cactus pear, the descending order in relation to the average amount is: $\mathrm{K}, \mathrm{Ca}, \mathrm{N}, \mathrm{Mg}, \mathrm{P}$ and $\mathrm{S}$. These data are in accordance with those found by Teles et al. (2002), who worked with cactus pear in a greenhouse, evaluating nutritional content and effect of nematicide.

For the values of $\mathrm{H}+\mathrm{Al}$ at the second sampling time (390 DAP), the fitted model estimates that the $\mathrm{H}+\mathrm{Al}$ content decreases by $0.002 \mathrm{cmol}_{\mathrm{c}} \mathrm{dm}^{-3}$ for each $\mathrm{Mg} \mathrm{ha}^{-1}$ year $^{-1}$ of bovine manure, while for the third sampling time (600 DAP) it estimates a reduction of $0.0063 \mathrm{cmol}_{\mathrm{c}} \mathrm{dm}^{-3}$ for each $\mathrm{Mg} \mathrm{ha}^{-1}$ year $^{-1}$ of bovine manure (Figure $1 \mathrm{~F}$ ).

Studies show that the addition of organic matter to the soil can cause a direct effect on the increase of $\mathrm{pH}$ and decrease of $\mathrm{Al}^{3+}$. This effect occurs due to the binding of $\mathrm{H}^{+}$ions with organic molecules, $\mathrm{Al}^{3+}$ complexation and increase in soil CEC saturation by bases (Caetano \& Carvalho, 2006; Souza et al., 2006; Pavinato \& Rosolem, 2008). This fact justifies the reduction of $\mathrm{H}+\mathrm{Al}$ in the soil as a function of the higher doses of bovine manure in the present study.

For the values of SB, CEC, T and V, the fitted model at the second sampling time (390 DAP) estimates increments of 0.0114 , $0.0114,0.0094 \mathrm{cmol}_{\mathrm{c}} \mathrm{dm}^{-3}$ and $0.07 \%$, respectively, for each $\mathrm{Mg} \mathrm{ha}^{-1}$ year ${ }^{-1}$ of bovine manure applied to the soil. At the third sampling time (600 DAP), the model estimates increments of $0.0263,0.0263,0.0203 \mathrm{cmol}_{c} \mathrm{dm}^{-3}$ and $0.27 \%$ for each $\mathrm{Mg} \mathrm{ha}^{-1}$ year $^{-1}$ of bovine manure, respectively (Figures $1 \mathrm{G}, \mathrm{H}$, I and J).

As a consequence of the neutralization of exchangeable acidity $\left(\mathrm{Al}^{3+}\right)$ after liming, the mean values of SB and CEC were equal at the second and third sampling times as a function of the manure doses applied.

After liming, combined with the application of the established manure doses in the treatments, the increase in $\mathrm{Ca}$ and $\mathrm{Mg}$ concentrations promoted by the limestone, as well as in nutrients and SOM promoted by the manure, reduced the potential acidity by increasing SOM and SB with consequent increments in base saturation, effective CEC and $\mathrm{T}$ at the second sampling time.

Along the crop cycle, the extraction of $\mathrm{K}^{+}, \mathrm{Ca}^{++}, \mathrm{Mg}^{++}$ and other nutrients, as well as the acidification caused by the decomposition of soil organic matter, the value of $\mathrm{H}+\mathrm{Al}$ increased again, with consequent reduction in the values of $\mathrm{SB}$, effective CEC, $\mathrm{T}$ and $\mathrm{V}$ at the third sampling time (600 DAP), except for treatments that received 60 and $90 \mathrm{Mg} \mathrm{ha}^{-1}$ year ${ }^{-1}$ of bovine manure, which guaranteed values within the class considered average (sufficient) of the parameters in question $\left(\mathrm{SB}=3.3-4.8 ; \mathrm{CEC}=3.3-4.8 ; \mathrm{T}=4.9-6.6 \mathrm{cmol}_{\mathrm{c}} \mathrm{dm}^{-3}\right.$ and $\mathrm{V}=$ 61.1-78.5\%) according to Donato et al. (2017b).

Soil $\mathrm{pH}$ varied linearly with increasing manure doses (Figure 2A). The model estimates an increase of 0.0042 units of $\mathrm{pH}$ for each $\mathrm{Mg} \mathrm{ha}^{-1}$ year ${ }^{-1}$ of bovine manure added. The increase in $\mathrm{pH}$ value for the highest manure dose $\left(90 \mathrm{Mg} \mathrm{ha}^{-1}\right.$ year $\left.^{-1}\right)$ compared to the dose zero $\mathrm{Mg} \mathrm{ha}^{-1}$ year $^{-1}$ was on the order of $7.27 \%$, from 5.5 to 5.9 .

The water-soluble organic compounds, originated from the decomposition of organic residues, complex cations of acidic reaction $\left(\mathrm{Fe}^{+2}, \mathrm{Mn}^{+2}\right.$ and $\left.\mathrm{Al}^{+3}\right)$ in the soil solution, releasing anions $\left(\mathrm{OH}^{-}, \mathrm{HCO}^{3-}\right)$ that cause aluminum precipitation and increase $\mathrm{pH}$ (Petrere \& Anghinoni, 2001).

The amount of $\mathrm{Mn}$ in the soil cultivated with 'Gigante' cactus pear under organic fertilization at different spacings varied linearly with increasing doses (Figure $2 \mathrm{~B}$ ). The model estimates an increase of $0.059 \mathrm{mg} \mathrm{dm}^{-3}$ for each $\mathrm{Mg} \mathrm{ha}^{-1}$ year $^{-1}$ of bovine manure added. The increase in Mn content at the highest dose of manure ( $90 \mathrm{Mg} \mathrm{ha}^{-1}$ year $\left.^{-1}\right)$ compared to zero $\mathrm{Mg} \mathrm{ha}^{-1}$ year $^{-1}$ was on the order of $22.5 \%$, from 25.7 to $31.5 \mathrm{mg} \mathrm{dm}^{-3}$.

Fertilization with 30, 60 and $90 \mathrm{Mg} \mathrm{ha}^{-1}$ year $^{-1}$ of bovine manure supplies 12, 24 and $36 \mathrm{~kg} \mathrm{ha}^{-1}$ year $^{-1}$ of Mn, respectively. 
Since the doses were applied twice, the supplied amounts were 24, 48 and $72 \mathrm{~kg}$ of $\mathrm{Mn} \mathrm{ha}^{-1}$, which explains the increase in its contents in the soil.

With the increase of soil organic matter concentrations as a result of the applied manure doses, there were changes in soil chemical attributes with reduction of $\mathrm{Al}^{3+}$ levels and consequent increments in $\mathrm{pH}$ and in the amount and availability of nutrients between the first and second soil sampling times, followed by a slight reduction at the third sampling time, resulting from the nutrient extraction by 'Gigante' cactus pear.

The values of $\mathrm{pH}, \mathrm{P}, \mathrm{Ca}$ and $\mathrm{V}$ in the soil were lower at $0 \mathrm{DAP}$ than at the other times (Table 1) because at the first sampling time there had been no liming or fertilization.

Soil pH was higher at 390 DAP compared to 0 DAP and 600 DAP for the three spacings evaluated. This fact can be explained by the liming performed between 0 DAP and 390 DAP, which led to similar results for $\mathrm{Ca}$ and $\mathrm{V}$.

The soil P concentration was higher in 600 DAP compared to 0 DAP and 390 DAP for the three spacings evaluated because the two fertilization events carried out at the first and second sampling times. As the manure contains large amounts of $\mathrm{P}$, which was released in the mineralization over 600 days, the stocks of available $\mathrm{P}$ in the soil reached higher levels than at the other times.

Cactus pear is highly efficient in extracting nutrients from the soil, due to its high phytomass production. It is a plant highly responsive to organic fertilization and, since the most soils of the semiarid region have low organic matter contents, the practice of fertilization is a necessity in the cultivation of this cactus species (Sales et al., 2014). In this context, the practice of adding organic fertilizers to the soil is therefore a way to maintain or improve its quality, increasing the content of organic matter and adding nutrients, which results in saving of mineral fertilizers (Marchi, 2006).

The addition of organic materials is fundamental for soil quality. The gradual release of nutrients by these materials reduces processes such as leaching, fixation and volatilization, despite depending essentially on the decomposition rate, controlled by soil temperature, moisture content, texture and mineralogy, besides the chemical composition of the organic material used (Zech et al., 1997).

In a forage production system in a semiarid environment, the adoption of organic fertilization management based on knowledge of soil chemical attributes combined with the understanding of the dynamics of cactus pear extraction throughout its production cycle is characterized as fundamental for a successful cultivation, as evidenced in the present study, in which organic fertilization was able to modify attributes that limit the production of most crops, besides providing essential nutrients for the full development of the crop, leading to the reduction in nutrient levels in the soil after 600 days of cultivation as a result of extraction for the formation of the plant architecture. In other words, it shows that it is necessary to continue organic fertilization with doses above $60 \mathrm{Mg} \mathrm{ha}^{-1}$ year $^{-1}$ in the production of 'Gigante' cactus pear to ensure the sufficiency levels of soil chemical attributes, leading to increments in its fertility and resilience.

\section{Conchusions}

1. Organic fertilization with 60 and $90 \mathrm{Mg} \mathrm{ha}^{-1}$ year $^{-1}$ of bovine manure reduces the potential acidity of the soil, increases the concentrations of macro and micronutrients, SOM, pH, CEC, T, SB, V, and maintains them at sufficiency values at 600 days after planting.

2. There is a reduction in soil $\mathrm{pH}, \mathrm{Ca}$ and $\mathrm{V}$ values and increase in $\mathrm{P}$ concentration along the cycle of cactus pear at different spacings.

\section{Literature Cited}

Blanco-Macías, F.; Magallanes-Quintanar, R.; Valdez-Cepeda, R. D.; Vázquez-Alvarado, R.; Olivares-Sáenz, E.; Gutiérrez-Ornelas, E.; Vidales-Contreras, J. A.; Murillo-Amador, B. Nutritional reference values for Opuntia ficus-indica determined by means of the boundary-line approach. Journal of Plant Nutrition and Soil Science, v.173, p.927-934, 2010. https://doi.org/10.1002/ jpln.200900147

Caetano, L. C. S.; Carvalho, A. J. C. de. Efeito da adubação com boro e esterco bovino sobre a produtividade da figueira e as propriedades químicas do solo. Ciência Rural, v.36, p.1150-1155, 2006. https:// doi.org/10.1590/S0103-84782006000400017

Cavalcante, L. A. D.; Santos, G. R. de A.; Silva, L. M. da; Fagundes, J. L.; Silva, M. A. da. Respostas de genótipos de palma forrageira a diferentes densidades de cultivo. Pesquisa Agropecuária Tropical, v.44, p.424-433, 2014. https://doi.org/10.1590/S198340632014000400010

Donato, P. E. R.; Donato, S. L. R.; Silva, J. A.; Pires, A. J. V.; Rosa, R. C. C.; Aquino, A. A. Nutrition and yield of 'Gigante' cactus pear cultivated with different spacings and organic fertilizer. Revista Brasileira de Engenharia Agrícola e Ambiental, v.20, p.10831088, 2016. https://doi.org/10.1590/1807-1929/agriambi. v20n12p1083-1088

Donato, P. E. R.; Donato, S. L. R.; Silva, J. A.; Pires, A. J. V.; Silva Junior, A. E A. Extraction/exportation of macronutrients by cladodes of 'Gigante' cactus pear under different spacing and organic fertilizer. Revista Brasileira de Engenharia Agrícola e Ambiental, v.21, p.238-243, 2017a. https://doi.org/10.1590/1807-1929/agriambi. v21n4p238-243

Donato, P. E. R.; Pires, A. J. V.; Donato, S. L. R.; Bonomo, P.; Silva, J. A.; Aquino, A. A. Morfometria e rendimento da palma forrageira 'Gigante' sob diferentes espaçamentos e doses de adubação orgânica. Revista Brasileira de Ciências Agrárias, v.9, p.151-158, 2014a. https://doi.org/10.5039/agraria.v9i1a3252

Donato, P. E. R.; Pires, A. J. V.; Donato, S. L. R.; Silva, J. A. da; Aquino, A. A. de. Valor nutritivo da palma forrageira 'Gigante' cultivada sob diferentes espaçamentos e doses de esterco bovino. Revista Caatinga, v.27, p.163-172, 2014b.

Donato, S. L. R.; Donato, P. E. R.; Silva, J. A.; Rodrigues, M. G. V. Diagnóstico nutricional e recomendação de adubação para a palma forrageira 'Gigante’. Informe Agropecuário, v.38, p.46-58, $2017 \mathrm{~b}$.

Lima, G. F. da C.; Rego, M. M. T.; Dantas, F. D. G.; Lôbo, R. N. B.; Silva, J. G. M. da. Morphological characteristics and forage productivity of irrigate cactus pear under different cutting intensities. Revista Caatinga, v.29, p.481-488, 2016. https://doi. org/10.1590/1983-21252016v29n226rc 
Marchi, E. C. S. Influência da adubação orgânica e de doses de material húmico sobre a produção de alface americana e teores de carbono no solo. Lavras: UFLA, 2006. 46p. Tese Doutorado

Novais, R. F. de; Smyth, T. J.; Nunes, F. N. Fósforo. In: Novais, R. F.; Alvarez V., V. H.; Barros, N. F. de; Fontes, L. E. F.; Cantarutti, R. B.; Neves, J. C. L. (eds.). Fertilidade do solo. Viçosa: Sociedade Brasileira de Ciência do Solo, 2007. Cap.8, 1017p.

Padilha Junior, M. C.; Donato, S. L. R.; Silva, J. A.; Donato, P. E. R.; Souza, E. S. Características morfométricas e rendimento da palma forrageira 'Gigante' sob diferentes adubações e configurações de plantio. Revista Verde de Agroecologia e Desenvolvimento Sustentável, v.11, p.67-72, 2016. https://doi.org/10.18378/rvads. v11i1.3710

Pavinato, P. S.; Rosolem, C. A. Disponibilidade de nutrientes no solo: Decomposição e liberação de compostos orgânicos de resíduos vegetais. Revista Brasileira de Ciência do Solo, v.32, p.911-920, 2008. https://doi.org/10.1590/S0100-06832008000300001

Petrere, C.; Anghinoni, I. Alteração de atributos químicos no perfil do solo pela calagem superficial em campo nativo. Revista Brasileira de Ciência do Solo, v.25, p.885-895, 2001. https://doi.org/10.1590/ S0100-06832001000400011

Sales, A. T.; Alves, A. Q.; Ramos, J. P. F.; Nascimento, J. P. do; Leite, M. L. D. M. V. Eficiência de utilização da adubação orgânica pela palma forrageira em função da densidade populacional. Revista Científica de Produção Animal, v.14, p.32-35, 2014. https://doi. org/10.15528/2176-4158/rcpa.v14n1p32-35

Silva, J. A. da; Bonomo, P.; Donato, S. L. R.; Pires, A. J. V.; Rosa, R. C. C.; Donato, P. E. R. Composição mineral de palma forrageira sob diferentes espaçamentos e adubações química. Revista Brasileira de Ciências Agrárias, v.7, p.866-875, 2012. https://doi. org/10.5039/agraria.v7isa2134

Silva, J. A. da; Bonomo, P.; Donato, S. L. R.; Pires, A. J. V.; Silva, F. F.; Donato, P. E. R. Composição bromatológica de cladódios de palma forrageira sob diferentes espaçamentos e adubações química. Revista Brasileira de Ciências Agrárias, v.8, p.342-350, 2013. https://doi.org/10.5039/agraria.v8i2a2431
Silva, J. A. da; Donato, S. L. R.; Donato, P. E. R.; Souza, E. dos S.; Padilha Junior, M. C.; Silva Junior, A. A. e. Extraction/export of nutrients in Opuntia ficus-indica under different spacings and chemical fertilizers. Revista Brasileira de Engenharia Agrícola e Ambiental, v.20, p.236-242, 2016a. https://doi.org/10.1590/18071929/agriambi.v20n3p236-242

Silva, J. A. da; Donato, S. L.; Donato, P. E. R.; Souza, E. dos S.; Padilha Junior, M. C.; Silva Junior, A. A. e. Yield and vegetative growth of cactus pear at different spacings and under chemical fertilizations. Revista Brasileira de Engenharia Agrícola e Ambiental, v.20, p.564-569, 2016b. https://doi.org/10.1590/18071929/agriambi.v20n6p564-569

Silva, L. M. da; Fagundes, J. L.; Viegas, P. A. A.; Muniz, E. N.; Rangel, J. H. de A.; Moreira, A. L.; Backes, A. A. Produtividade da palma forrageira cultivada em diferentes densidades de plantio. Ciência Rural, v.44, p.2064-2071, 2014. https://doi.org/10.1590/0103$8478 \mathrm{cr} 20131305$

Souto, P. C.; Souto, J. S.; Santos, R. V. Decomposição de estercos dispostos em diferentes profundidades em área degradada no Semiárido da Paraíba. Revista Brasileira de Ciências do Solo, v.29, p.125-130. 2005. https://doi.org/10.1590/S010006832005000100014

Souza, R. F.; Faquim, V.; Torres, P. R. F.; Baliza, D. P. Calagem e adubação orgânica: Influencia na adsorção de fósforo em solos. Revista Brasileira de Ciências do Solo, v.30, p.975-983, 2006. https://doi.org/10.1590/S0100-06832006000600007

Teles, M. M.; Santos, M. V. F.; Dubeux Júnior, J. C. B.; Bezerra Neto, E.; Ferreira, R. L. C.; Lucena, J. E. C.; Lira, M. A. Efeitos da adubação e de nematicida no crescimento e na produção da palma forrageira (Opuntia fícus-indica Mill.) cv. Gigante. Revista Brasileira de Zootecnia, v.31, p.52-60, 2002. https://doi.org/10.1590/S151635982002000100006

Zech, Z.; Senesi, N.; Guggenberger, G.; Kaiser, K.; Lehmann Miano, T. M.; Miltner, A.; Schroth, G. Factors controlling humification and mineralization of soil organic matter in tropics. Geoderma, v.79, p.117-161, 1997. https://doi.org/10.1016/S0016-7061(97)00040-2 